\title{
Response to Chemotherapy, Reexposure to Crizotinib and Treatment with a Novel ALK Inhibitor in a Patient with Acquired Crizotinib Resistance
}

\author{
Kathrin Schrödl Christoph von Schilling Amanda Tufman Rudolf Maria Huber \\ Fernando Gamarra \\ Department of Internal Medicine V, University of Munich, Comprehensive Pneumology Center, Member of the German \\ Center for Lung Research, Munich, Germany
}

\section{Established Facts}

- Crizotinib treatment of ALK-positive patients with non-small cell lung cancer (NSCLC) leads to a median progression-free survival of 9.7 months.

\section{Novel Insights}

- Crizotinib retreatment of ALK-positive patients with secondary resistance to crizotinib after a drug holiday and conventional chemotherapy improves crizotinib sensitivity.

- A good response to the new ALK inhibitor LDK 378 was obtained in a case of NSCLC after two treatments with crizotinib.

\section{Key Words}

ALK inhibitor · Crizotinib · Crizotinib resistance · LDK 378 . Lung cancer

\begin{abstract}
The treatment of advanced non-small cell lung cancer (NSCLC) has dramatically changed over the last decade. It has developed from an unspecific approach based on platinum doublet chemotherapy to a personalized, molecularly targeted therapy. Crizotinib is a new tyrosine kinase inhibitor approved for the treatment of NSCLC with gene rearrangement of EML4 and ALK. Despite good initial responses, patients treated with crizotinib relapse after an average of 10 months. In this case report, we present a patient with ac-
\end{abstract}

\section{KARGER}

E-Mail karger@karger.com www.karger.com/res quired crizotinib resistance whose adenocarcinoma responded to a second course of crizotinib following a drug holiday and chemotherapy with pemetrexed. This is the second case report to suggest that retreatment with crizotinib is an option for patients with initial benefit from ALK inhibition.

(c) 2014 S. Karger AG, Basel

\section{Introduction}

The treatment of advanced non-small cell lung cancer (NSCLC) has dramatically changed over the last decade and has developed from an unspecific approach based on platinum doublet chemotherapy to a personalized, mo- 
lecularly targeted therapy [1-4]. Crizotinib is a new tyrosine kinase inhibitor (TKI) approved for the treatment of NSCLC with gene rearrangement of EML4 and ALK [5]. Treatment with new TKIs, e.g. crizotinib, is often limited by the development of secondary crizotinib resistance, which ultimately limits the life expectancy of patients [4]. Therefore, in case of acquired crizotinib resistance, new therapeutic strategies are needed. The following case report describes successful management of crizotinib resistance.

\section{Case Report}

A 70-year-old male patient (white, never-smoker) was diagnosed with adenocarcinoma [wild-type epidermal growth factor receptor (EGFR), EML4/ALK translocation positive] of the right upper lobe of the lung in February 2009.

The patient was initially diagnosed and treated at a community hospital and was referred to our department following second-line treatment for a second opinion. The stage at first diagnosis was cIIIA ( $\mathrm{cT} 2 \mathrm{cN} 2 \mathrm{cM} 0)$ and the patient was enrolled in a clinical trial and received neoadjuvant chemotherapy with three cycles of cisplatin and vinorelbin combined with cetuximab at cycle two and three. PET-CT then showed a partial remission, and resection was planned. Unfortunately, the thoracotomy revealed inoperable mediastinal pleural infiltration and the procedure was terminated. The patient was then treated with combined radiochemotherapy with $54 \mathrm{~Gy}$ at the primary tumor site as well as two further cycles of cisplatin and vinorelbin. Following a 5-month period of progression-free survival, a follow-up PET-CT showed recurrent tumor at the primary tumor site and along the right inner thoracic wall. Second-line systemic therapy with the EGFR-TKI erlotinib was initiated, but the tumor progressed after 4 months, causing clinically relevant multifocal cutaneous metastases, pleural carcinomatosis and total atelectasis of the right lung. A third-line systemic therapy with pemetrexed was initiated and the patient was referred to our center. Chemotherapy with pemetrexed was administered for two cycles. Prior to chemotherapy with pemetrexed, the primary tumor occupied most of the upper lobe with pleural and chest wall infiltration and obstruction of the intermediate bronchus. In addition, involvement of subcarinal and bilateral axillary lymph nodes was detected. Pemetrexed treatment induced shrinkage of the contralateral lymph nodes; however, no relevant change in the remaining sites involved was noticed. Therefore, a clinically meaningful response could not be established. Screening for the EML4-ALK gene rearrangement assessed by ALK FISH break apart test was positive, and therefore the patient was included in a clinical trial with crizotinib dosed at $250 \mathrm{mg}$ twice daily. Treatment with crizotinib led to a partial remission with disappearance of the cutaneous metastases, better ventilation of the right lung and a reduction in exertional dyspnea. Following 6 months of crizotinib, the primary tumor showed slight radiographic progression; however, the patient remained clinically stable on treatment for an additional 3 months. Due to increasing cough and thoracic pain, crizotinib was then discontinued and the treat- ment had to be changed to a conventional chemotherapy. According to the clinical data, both pemetrexed and docetaxel have a similar effect for second-line therapy of NSCLC. We considered both options, but the patient opted for pemetrexed instead of docetaxel, because of the more favorable toxicity profile of the former agent. Accordingly, the patient was treated with four cycles of pemetrexed. This resulted in a partial response and improvement in symptoms.

Due to pemetrexed-associated neutropenia, pemetrexed was then discontinued and the patient was monitored clinically and radiologically. He remained stable for a period of 8 months before tumor progression prompted us to retreat with crizotinib.

Retreatment with crizotinib led to a rapid and substantial improvement in the quality of life. CT confirmed significant remission of the intrathoracic tumor burden. Following 9 months of retreatment with crizotinib, the patient developed brain metastasis. Crizotinib was discontinued and the patient was included in a study with LDK 378, a novel ALK inhibitor for crizotinib-resistant ALK-positive NSCLC. At this time, the patient remains under LDK 378 therapy and is in good general condition. Follow-up CT scans have shown regression of the intrathoracic tumor masses as well as the brain metastasis. Thus far, radiation of brain metastasis has not been performed.

\section{Discussion}

EML4-ALK rearrangements result in an abnormal expression of ALK and subsequent activation of intracellular signaling pathways in a subset of NSCLC cells. Patients with ALK-positive tumors respond well to treatment with ALK inhibitors $[4,6]$. Crizotinib is an orally available, clinically well-tolerated TKI of ALK. Treatment of ALKpositive NSCLC patients with crizotinib leads to a median progression-free survival of 9.7 months $[4,7]$. Unfortunately, secondary resistance to crizotinib invariably develops, limiting the life expectancy of these patients $[7,8]$. Our patient developed secondary crizotinib resistance with slow progression of his tumor after 9 months of crizotinib. Previous publications regarding the retreatment of patients with secondary resistance to EGFR-TKIs suggest that a drug holiday and treatment with a conventional chemotherapeutic may reestablish sensitivity to TKIs $[9,10]$. Although this strategy is well described for EGFR-TKIs, there is to date only one case report indicating that crizotinib retreatment of ALK-positive patients after a drug holiday and chemotherapy improves crizotinib sensitivity [11]. This case report illustrates that patients with secondary resistance to crizotinib can benefit from a range of therapeutic strategies, including drug holiday, chemotherapy, retreatment with crizotinib and treatment with new ALK inhibitors in clinical trials. This is the first case report describing a good response to the 
new ALK inhibitor LDK 378 after two treatments with crizotinib. These observations illustrate the therapeutic options for crizotinib-resistant EML4-ALK-positive patients.

\section{Financial Disclosure and Conflicts of Interest}

All authors declare no conflict of interest.

\section{References}

1 Scagliotti GV, Parikh P, von Pawel J, Biesma B, Vansteenkiste J, Manegold C, Serwatowski P, Gatzemeier U, Digumarti R, Zukin M, Lee JS, Mellemgaard A, Park K, Patil S, Rolski J, Goksel T, de Marinis F, Simms L, Sugarman KP, Gandara D: Phase III study comparing cisplatin plus gemcitabine with cisplatin plus pemetrexed in chemotherapy-naive patients with advanced-stage non-small-cell lung cancer. J Clin Oncol 2008;26:3543-3551.

-2 Reck M, von Pawel J, Zatloukal P, Ramlau R, Gorbounova V, Hirsh V, Leighl N, Mezger J, Archer V, Moore N, Manegold C: Phase III trial of cisplatin plus gemcitabine with either placebo or bevacizumab as first-line therapy for nonsquamous non-small-cell lung cancer: AVAil. J Clin Oncol 2009;27:1227-1234.

-3 Maemondo M, Inoue A, Kobayashi K, Sugawara S, Oizumi S, Isobe H, Gemma A, Harada M, Yoshizawa H, Kinoshita I, Fujita Y, Okinaga S, Hirano $\mathrm{H}$, Yoshimori $\mathrm{K}$, Harada T, Ogura T, Ando M, Miyazawa H, Tanaka T, Saijo Y, Hagiwara K, Morita S, Nukiwa T: Gefitinib or chemotherapy for non-small-cell lung cancer with mutated EGFR. N Engl J Med 2010;362:2380-2388.
4 D'Arcangelo M, Wynes MW, Hirsch FR: The role of anaplastic lymphoma kinase inhibitors in the treatment of advanced nonsmall cell lung cancer. Curr Opin Oncol 2013;25:121129.

5 Timm A, Kolesar JM: Crizotinib for the treatment of non-small-cell lung cancer. Am J Health Syst Pharm 2013;70:943-947.

6 Gridelli C, Solange P, Sgambato A, Casaluce F, Adjei AA, Ciardiello F: ALK inhibitors in the treatment of advanced NSCLC. Cancer Treat Rev 2014;40:300-306.

7 Camidge DR, Bang YJ, Kwak EL, Iafrate AJ, Varella-Garcia M, Fox SB, Riely GJ, Solomon B, Ou SH, Kim DW, Salgia R, Fidias P, Engelman JA, Gandhi L, Janne PA, Costa DB, Shapiro GI, Lorusso P, Ruffner K, Stephenson P, Tang Y, Wilner K, Clark JW, Shaw AT: Activity and safety of crizotinib in patients with ALK-positive non-small-cell lung cancer: updated results from a phase 1 study. Lancet Oncol 2012;13:1011-1019.
8 Kwak EL, Bang YJ, Camidge DR, Shaw AT, Solomon B, Maki RG, Ou SH, Dezube BJ, Janne PA, Costa DB, Varella-Garcia M, Kim WH, Lynch TJ, Fidias P, Stubbs H, Engelman JA, Sequist LV, Tan W, Gandhi L, Mino-Kenudson M, Wei GC, Shreeve SM, Ratain MJ, Settleman J, Christensen JG, Haber DA, Wilner K, Salgia R, Shapiro GI, Clark JW, Iafrate AJ: Anaplastic lymphoma kinase inhibition in non-small-cell lung cancer. N Engl J Med 2010;363:1693-1703

9 Becker A, Crombag L, Heideman DA, Thunnissen FB, van Wijk AW, Postmus PE, Smit EF: Retreatment with erlotinib: regain of TKI sensitivity following a drug holiday for patients with NSCLC who initially responded to EGFR-TKI treatment. Eur J Cancer 2011;47: 2603-2606.

10 Zhao X, Han R, Wang J, Yang F, Zhong W, Zhang L, Li L, Wang M: Comparison of epidermal growth factor receptor mutation statuses in tissue and plasma in stage I-IV nonsmall cell lung cancer patients. Respiration 2013;85:119-125.

11 Browning ET, Weickhardt AJ, Camidge DR: Response to crizotinib rechallenge after initial progression and intervening chemotherapy in ALK lung cancer. J Thorac Oncol 2013; 8:e21. 